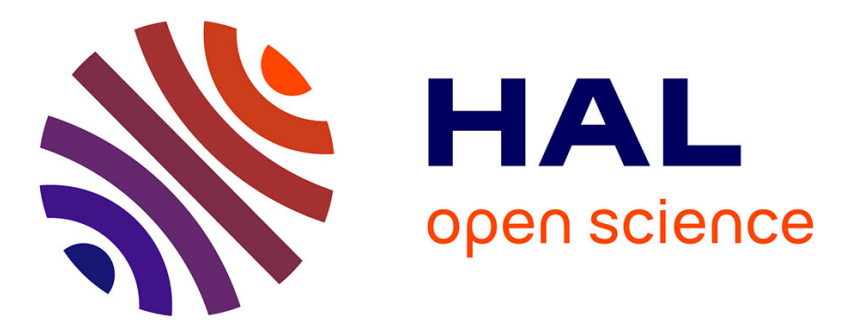

\title{
Changes in tissue amino acid composition and protein metabolism in piglets due to a limiting supply of total sulphur amino acids
}

Jose Alberto Conde-Aguilera, Carlos Cobo Ortega, Nathalie Le Floc'H, Y. Mercier, Jaap J. van Milgen

\section{To cite this version:}

Jose Alberto Conde-Aguilera, Carlos Cobo Ortega, Nathalie Le Floc'H, Y. Mercier, Jaap J. van Milgen. Changes in tissue amino acid composition and protein metabolism in piglets due to a limiting supply of total sulphur amino acids. 4th International symposium on energy and protein metabolism and nutrition, Sep 2013, Sacramento, United States. Wageningen Academic Publishers, EAAP Publication, 134, 2013, EAAP Publication. hal-01210462

\section{HAL Id: hal-01210462 \\ https://hal.science/hal-01210462}

Submitted on 3 Jun 2020

HAL is a multi-disciplinary open access archive for the deposit and dissemination of scientific research documents, whether they are published or not. The documents may come from teaching and research institutions in France or abroad, or from public or private research centers.
L'archive ouverte pluridisciplinaire HAL, est destinée au dépôt et à la diffusion de documents scientifiques de niveau recherche, publiés ou non, émanant des établissements d'enseignement et de recherche français ou étrangers, des laboratoires publics ou privés. 
due to a limiting supply of total sulphur amino acids

J.A. Conde-Aguilera',2, C. Cobo-Ortega 1,2, N. Le Floc' $h^{1,2}$, Y. Mercier, J. van Milgen 1,2

'IINRA, UMR1348 PEGASE, Saint-Gilles, France, ${ }^{2}$ Agrocampus Ouest, UMR1348 PEGASE, Rennes, France, ${ }^{3}$ Adisseo France SAS, Antony, France.

\section{Introduction \& Objective}

In pigs, the amino acid requirements are usually evaluated through body weight gain or $\mathrm{N}$ retention, which assume that the amino acid composition of the total body protein is constant. However, there are doubts on the validity of this hypothesis. A deficient total sulphur amino acids (Met+Cys) supply has been shown to modify the amino acid profile of tissue proteins (Conde-Aguilera et al., 2010), but mechanisms are still unknown.

The objective of this study was to evaluate the response of piglets to a deficient total sulphur amino acid supply in terms of protein synthesis, activities of proteolytic enzymes, and the amino acid composition of body tissues.

\section{Materials \& Methods}

Piglets were divided in 2 groups and received a diet either deficient (TSAA-) or sufficient (TSAA+) in total sulphur amino acids for $10 \mathrm{~d}$. Diets were formulated to meet the nutrition recommendations except for the Met and total sulphur amino acid supplies in TSAAwhich were
for analysis.

$$
\begin{aligned}
& 25 \% \text { below the ad libitum } \\
& \text { intake capacity }
\end{aligned}
$$

intake capacity

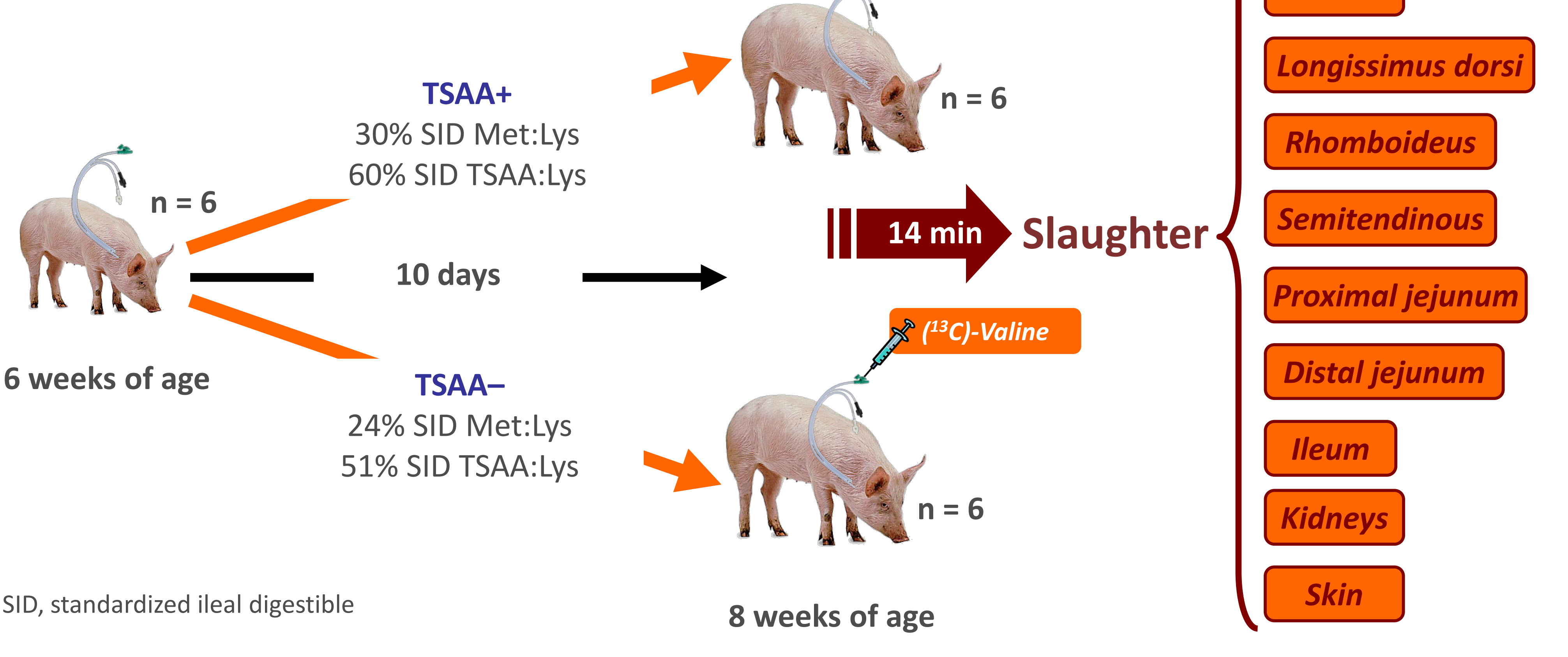

\section{Results \& Discussion}

Performance and muscle protein metabolism

\begin{tabular}{|c|c|c|c|}
\hline & TSAA+ & TSAA- & $P$-value \\
\hline Final BW (kg) & 13.0 & 12.3 & 0.24 \\
\hline Weight gain (g/d) & 375 & 292 & $<0.001$ \\
\hline Feed conversion ( $\mathrm{g}$ gin $/ \mathrm{g}$ feed) & 0.99 & 0.78 & $<0.01$ \\
\hline \multicolumn{4}{|l|}{ Protein synthesis (\%/d) } \\
\hline Longissimus dorsi & 6.35 & 4.33 & $<0.01$ \\
\hline Rhomboideus & 3.85 & 4.20 & 0.39 \\
\hline Semitendinous & 4.95 & 4.11 & 0.10 \\
\hline \multicolumn{4}{|l|}{ Efficiency of protein synthesis } \\
\hline Longissimus dorsi & 4.91 & 2.95 & $<0.001$ \\
\hline Rhomboideus & 4.06 & 4.38 & 0.43 \\
\hline Semitendinous & 3.80 & 2.98 & 0.03 \\
\hline \multicolumn{4}{|l|}{ Proteasome activity $^{2}$} \\
\hline Longissimus dorsi & 1,959 & 2,170 & 0.39 \\
\hline Rhomboideus & 2,788 & 2,741 & 0.88 \\
\hline Semitendinous & 1,914 & 2,284 & 0.05 \\
\hline
\end{tabular}

Relative weight and protein content of tissues

\begin{tabular}{|c|c|c|c|c|c|c|c|}
\hline & \multicolumn{3}{|c|}{ SSAAt } & & \multicolumn{3}{|c|}{ ISAA+ TSAA- - -value } \\
\hline Neight $(\mathbf{g} / \mathrm{kg} \mathrm{BW})$ & & & & Protein (g/kg tissue) & & & \\
\hline Longissimus dorsi & 17.1 & 15.4 & 0.09 & Longissimus dorsi & 176 & 176 & \\
\hline Rhomboideus & 0.42 & 0.42 & 0.93 & Rhomboideus & 154 & 156 & 0.51 \\
\hline Semitendinous & 3.43 & 3.45 & 0.88 & Semitendinous & 162 & 165 & 0.48 \\
\hline Liver & 24.1 & 24.6 & 0.60 & Liver & 169 & 174 & \\
\hline Proximal jejunum & 11.2 & 11.7 & 0.67 & Proximal jejunum & 131 & 135 & \\
\hline Distal jejunum & 10.8 & 13.2 & 0.01 & Distal jejunum & 122 & 126 & 0.53 \\
\hline Ileum & 12.4 & 13.5 & 0.51 & Heum & 119 & 131 & 0.07 \\
\hline Kidneys & 5.45 & 5.55 & 0.78 & Kidneys & 135 & 136 & 0.64 \\
\hline Skin & 2.67 & 2.50 & 0.91 & Skin & 186 & 194 & 0.44 \\
\hline
\end{tabular}

Amino acid composition of longissimus dorsi (LM), rhomboideus (RM) and semitendinous (SM) muscles, liver, proximal and distal jejunum, ileum, kidney and skin
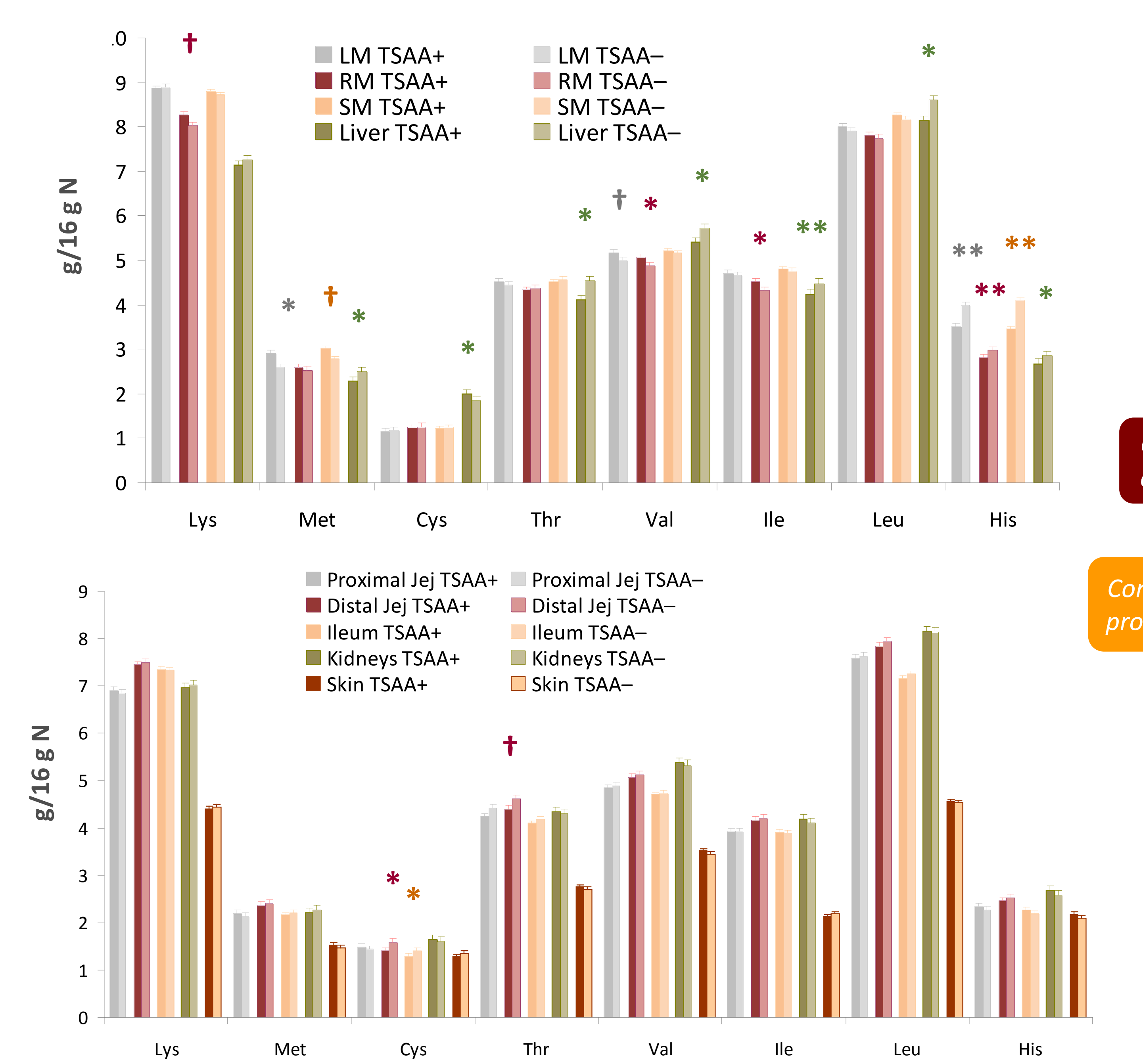

\section{${ }^{*} \mathrm{P} \leq 0.05,{ }^{*} * \mathrm{P} \leq 0.01,+\mathrm{P} \leq 0.10$}

Conclusion

The animal shows a certain plasticity of tissues to respond to a limiting total sulphur amino acid supply. This questions the use of a constant amino acid profile to establish amino acid requirements. The functional consequences of these changes remain to be studied.

$$
\text { References }
$$

Conde-Aguilera, J. A., R. Barea, N. Le Floc'h, L. Lefaucheur and J. van Milgen, 2010. Animal 4,1349-1358. Richie, J. P., D. Komninou, Y. Leutzinger, W. Kleinman, N. Orentreich, V. Malloy and J. A. Zimmerman, 2004 